\title{
ANALISIS FAKTOR KESULITAN BELAJAR PADA MATA PELAJARAN ILMU PENGETAHUAN ALAM (IPA) SISWA KELAS VII MTS BATAMIYAH BATAM
}

\section{FACTOR ANALYSIS OF LEARNING DIFFICULTIES IN SUBJECT OF NATURAL SCIENCE CLASS VII MTS BATAMIYAH BATAM}

\author{
Zikkra Evita ${ }^{1}$, Rahmi $^{2}$, Yarsi Efendi ${ }^{2}$ \\ ${ }^{1}$ Alumni Program Studi Pendidikan Biologi, FKIP, Universitas Riau Kepulauan, Batam \\ ${ }^{2}$ Dosen Program Studi Pendidikan Biologi, FKIP, Universitas Riau Kepulauan, Batam
}

Koresponden: rahmikumbang@gmail.com

\begin{abstract}
Abstrak
Penelitian ini bertujuan untuk mengetahui kesulitan yang dialami siswa dalam belajar IPA dan faktor-faktor apa saja yang menyebabkannya. Subjek penelitian ini adalah siswa kelas VII MTs Batamiyah Batam. Metode yang digunakan dalam penelitian ini adalah metode deskriptif. Data yang berupa hasil belajar dikumpulkan, sedangkan data yang berupa respons siswa terhadap pembelajaran IPA menggunakan lembar observasi dan kuesioner. Siswa yang mendapat nilai di bawah KKM berarti mengalami kesulitan belajar dalam memahami pelajaran IPA. Faktor yang mempengaruhi kesulitan belajar berasal dari diri sendiri sebesar $70.9 \%$, dari lingkungan keluarga sebesar 50. $1 \%$, dan dari lingkungan sekolah sebesar $68.9 \%$
\end{abstract}

Kata Kunci: Kesulitan belajar, Analisis diskripstif, IPA

\begin{abstract}
This study aims to determine the difficulties experienced by students in learning science and what factors are causing it. The subjects were students of class VII MTs Batamiyah Batam. The method used in this research is descriptive method. The data collected in the form of learning outcomes, while the data in the form of a student's response to science teaching using observation sheets and questionnaires. Students who scored below the KKM means learning difficulties in understanding the science lessons. Factors affecting learning difficulties comes from yourself by 70.9\%, from the family of 50. 1\%, and of the school environment by $68.9 \%$
\end{abstract}

Keywords: Difficulties of learning, Analysis discriptive, Natural science

\section{PENDAHULUAN}

Sebuah proses belajar mengajar di dunia pendidikan tidak selamanya mengalami kelancaran. Umumnya hambatan yang terjadi seperti adanya kesulitan belajar dalam diri peserta didik. Kesulitan belajar tersebut akan akan berdampak pada penurunan prestasi akademik dari peserta didik. Guru sebagai pendidik dituntut untuk bertanggung jawab atas perkembangan peserta didik. Karena itu guru dalam proses pembelajaran harus memperhatikan kemampuan peserta didik secara individual, agar dapat membantu 
perkembangan peserta didik secara optimal dan mengenali peserta didikm yang mengalami kesulitan belajar.

Pembelajaran IPA merupakan salah satu pelajaran yang dianggap sulit oleh siswa karena siswa beranggapan bahwa mata pelajaran IPA bersifat abstrak sedangkan pikiran siswa bersifat kongkrit, banyaknya penggunaan bahasa ilmiah dan istilah latin membuat siswa kesulitan untuk menghafal dan memahaminya. Selain itu alokasi waktu pembelajaran yang terbatas sedangkan materi pelajaran yang dipelajari lebih banyak diduga juga merupakan salah satu penyebab siswa mengalami kesulitan belajar.

Berdasarkan observasi awal dan wawancara yang dilakukan penulis terhadap guru IPA kelas VII di MTs Batamiyah Batam pada hari Kamis tanggal 2 April 2015 ditemukan masih banyak kendala yang dihadapi oleh para siswa, yaitu masalah kesulitan belajar. Salah satu mata pelajaran yang menyebabkan para siswa kelas VII ini mengalami kesulitan belajar yaitu mata pelajaran IPA.Hal tersebut dapat dilihat dari nilai ulangan harian dan nilai ujian akhir semester mata pelajaran IPA, hampir seluruh siswa kelas VII mendapat nilai di bawah KKM yaitu 65. Kesulitan belajar IPA pada sekolah tersebut meliputi : kurang ketertarikkan siswa terhadap pelajaran IPA, siswa menganggap bahawa mata pelajaran IPA lebih sulit dibandingkan mata pelajaran lain karena banyak menggunakan bahasa ilmiah, kesulitan pada pemahaman konsep/materi yang bersifat abstrak, dan waktu pembelajaran yang terbatas. Untuk itu tujuan melakukan penelitian adalah bagaimana mengetahui dan menganalisis faktor kesulitan belajar pelajaran Ilmu Pengetahuan Alam (IPA) Siswa kelas VII.

\section{METODOLOGI}

Jenis penelitian ini adalah penelitian deskriptif. Subyek penelitian ini adalah siswa-siswa kelas VII MTs Batamiyah Batam tahun ajaran 2014/2015 yang mengalami kesulitan belajar IPA pada 2 (dua): kelas VII A dan VII B, dengan kemampuan setiap kelas homogen. Siswa dipilih berdasarkan hasil analisis nilai tes ulangan harian dengan komptensi dasar klasifikasi makhluk hidup yang diperoleh dari guru atau tidak memenuhi KKM (Kriteria Ketuntasan Minimal) sebanyak 45 siswa. Terdapat dua variabel dalam penelitian ini yaitu: a) Variabel bebas (independent variabel) adalah variabel yang mempengaruhi atau yang menjadi sebab perubahannya atau timbulnya variabel terikat. Pada penelitian ini yang jadi variabel 
bebas adalah faktor kesulitan belajar $(\mathrm{X})$; dan b) Variabel terikat (dependent variabel) merupakan variabel yang dipengaruhi atau yang menjadi akibat, karena adanya variabel bebas. Pada penelitian ini yang menjadi variabel terikat yaitu hasil belajar IPA siswa (Y).

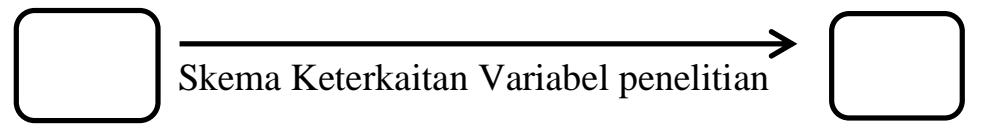

Keterangan:

$X=$ faktor kesulitan belajar: $Y=$ hasil belajar siswa

Tabel 1. Kriteria Persentase Analisis Deskriptif

\begin{tabular}{lcc}
\hline No. & Persentase & Kriteria \\
\hline 1. & $75 \%-100 \%$ & Sangat Tinggi \\
\hline 2. & $50 \%-75 \%$ & Tinggi \\
\hline 3. & $25 \%-50 \%$ & Rendah \\
\hline 4. & $1 \%-25 \%$ & Sangat Rendah \\
\hline
\end{tabular}

Selanjutnya dilakukan uji prasyarat analisis meliputi uji normalitas menggunakan uji Chi Kuadrat dan linieritas menggunakan uji F dan signifikasi 5\%. Pengujian hipotesis dilakukan untuk melihat hubungan fungsional antara dua variabel. Pengujian hipotesis dari penelitian ini menggunakan korelasi product moment untuk memperoleh nilai koefisien korelasi (r).

Tabel 2. Interprestasi Nilai Koefisien Korelasi (r)

\begin{tabular}{cc}
\hline Interval Koefisien & Tingkat Hubungan \\
\hline $0,00-0,199$ & Sangat rendah \\
$0,20-0,399$ & Rendah \\
$0,40-0,599$ & Sedang \\
$0,60-0,799$ & Kuat \\
$0,80-1,000$ & Sangat kuat \\
\hline
\end{tabular}

\section{PEMBAHASAN}

Faktor kesulitan belajar siswa pada mata pelajaran Ilmu Pengetahuan Alam dapat dilihat dari hasil jawaban terhadap angket yang diberikan.Kesulitan belajar yang dialami siswa dilihat dari tiga indikator yaitu diri sendiri, lingkungan keluarga, dan lingkungan sekolah. Berdasarkan Tabel 3. dapat disimpulkan bahwa, faktor yang mempengaruhi kesulitan belajar lebih dominan berasal dari diri sendiri dan lingkungan sekolah. Faktor yang berasal dari diri sendiri sebesar $70.9 \%$, yang terdiri dari 4 aspek yaitu (1) aspek minat, (2) aspek motivasi, (3) aspek intelegensi, (4) aspek kesehatan fisik dan dari lingkungan sekolah sebesar $68.9 \%$, sedangkan faktor yang berasal dari lingkungan keluarga memilki pengaruh yang lebih kecil yaitu sebesar $50.6 \%$. 
Tabel 3. Hasil Perhitungan Angket Faktor Kesulitan Belajar

\begin{tabular}{|c|c|c|c|c|c|c|c|c|c|c|c|c|c|}
\hline \multirow[b]{2}{*}{ No } & \multirow{2}{*}{$\begin{array}{c}\text { Faktor yang } \\
\text { mempengaruhi } \\
\text { kesulitan belajar }\end{array}$} & \multicolumn{10}{|c|}{ Pernyataan } & \multirow[b]{2}{*}{$\%$} & \multirow{2}{*}{$\begin{array}{c}\text { Kriteria } \\
*\end{array}$} \\
\hline & & $\begin{array}{l}\text { SS } \\
(+)\end{array}$ & $\begin{array}{l}\text { SS } \\
(-)\end{array}$ & $\begin{array}{c}S \\
(+)\end{array}$ & $\begin{array}{l}S \\
(-)\end{array}$ & $\begin{array}{c}\text { RG } \\
(+)\end{array}$ & $\begin{array}{c}\text { RG } \\
(-)\end{array}$ & $\begin{array}{l}\text { TS } \\
(+)\end{array}$ & $\begin{array}{l}\text { TS } \\
(-)\end{array}$ & $\begin{array}{c}\text { STS } \\
(+)\end{array}$ & $\begin{array}{c}\text { STS } \\
(-)\end{array}$ & & \\
\hline \multirow[t]{3}{*}{1} & Diri Sendiri & 3.5 & 5. & 12. & 16. & 5.7 & 3.7 & 35.2 & 2.2 & 13.1 & 1.1 & 70.9 & Tinggi \\
\hline & & $\%$ & 8 & $9 \%$ & $8 \%$ & $\%$ & $\%$ & $\%$ & $\%$ & $\%$ & $\%$ & $\%$ & \\
\hline & & & $\%$ & & & & & & & & & & \\
\hline \multirow[t]{3}{*}{2} & Lingkungan & - & 3. & 34. & 31. & $5 \%$ & - & 12.8 & 8.9 & 2.8 & 1.1 & 50.6 & Tinggi \\
\hline & Keluarga & & 3 & $5 \%$ & $7 \%$ & & & $\%$ & $\%$ & $\%$ & $\%$ & $\%$ & \\
\hline & & & $\%$ & & & & & & & & & & \\
\hline \multirow[t]{3}{*}{3} & Lingkungan & $5 \%$ & 3. & 4.4 & 11. & 11.7 & 0.5 & 37.8 & 8.3 & 16.1 & 1.1 & 68.9 & Tinggi \\
\hline & Sekolah & & 3 & $\%$ & $7 \%$ & $\%$ & $\%$ & $\%$ & $\%$ & $\%$ & $\%$ & $\%$ & \\
\hline & & & $\%$ & & & & & & & & & & \\
\hline
\end{tabular}

Keterangan : SS = Sangat Setuju, $\mathrm{S}=$ Setuju, $\mathrm{RG}=$ Ragu-ragu, $\mathrm{TS}=$ Tidak Setuju, STS $=$ Sangat Tidak Setuju

Dari ketiga faktor yang mempengaruhi kesulitan belajar yang dialami siswa, faktor yang paling mempengaruhi kesulitan belajar siswa yaitu dari diri sendiri, kemudian dari lingkungan sekolah, dan faktor yang paling kecil mempengaruhi kesulitan belajar adalah dari lingkungan keluarga meskipun kategori kesulitannya masih dalam kriteria tinggi.

Tabel 4. Rekapitulasi Tingkat Kesulitan Belajar Siswa

\begin{tabular}{|c|c|c|c|c|c|}
\hline \multirow[t]{2}{*}{ Indikator } & \multicolumn{4}{|c|}{ Keterangan } & \multirow[t]{2}{*}{ Total } \\
\hline & ST & $\mathbf{T}$ & $\mathbf{S}$ & $\mathbf{R}$ & \\
\hline 1. Diri Sendiri & - & 34 & 11 & - & 45 siswa \\
\hline 2. Lingkungan Keluarga & 1 & 38 & 6 & - & 45 siswa \\
\hline 3. Lingkungan Sekolah & 1 & 24 & 20 & - & 45 siswa \\
\hline Rata-rata & 0.7 & 32 & 12.3 & - & 45 siswa \\
\hline Pesentase & $1.6 \%$ & $71.1 \%$ & $27.3 \%$ & - & $100 \%$ \\
\hline
\end{tabular}

Keterangan : ST $=$ SangatTinggi, $\mathrm{T}=$ Tinggi, $\mathrm{S}=$ Sedang, $\mathrm{R}=$ Rendah

Berdasarkan Tabel 4. di atas dapat dilihat siswa mengalami kesulitan belajar yang berasal dari faktor diri sendiri yaitu 34 siswa mengalami kategori inggi, dan 11 siswa kategori rendah. Faktor lingkungan keluarga sebanyak 1 siswa mengalami kesulitan kategori sangat tinggi, 38 siswa kategori tinggi, dan 6 siswa kategori sedang sedangkan kesulitan yang dialami siswa dari faktor lingkungan sekolah, yaitu 1 siswa mengalami kesulitan kategori sangat tinggi, 24 siswa kategori tinggi, dan 20 siswa kategori sedang.

Hasil observasi diasumsikan menjadi salah satu faktor penyebab kesulitan belajar siswa pada mata pelajaran IPA, baik dilihat dari kegiatan siswa maupun dari keadaan/kondisi kelas, diantaranya; a) Kegiatan siswa, banyak diantaranya siswa tidak mengikuti kegiatan pembelajaran dengan sungguh-sungguh dan penuh kesiapan. Hal ini 
dapat dilihat dari kurangnya siswa dalam mengajukan dan menjawab pertanyaan; b) Keadaan kelas, kurangnya media pembelajaran yang dapat digunakan khususnya pada mata pelajaran IPA sehingga berdampak pada ketertarikan atau minat siswa dalam mempelajari mata pelajaran IPA yang bersifat teori dan banyak menggunakan bahasa ilmiah sehingga merasa pembelajaran yang dialami monoton.

Berdasarkan hasil penelitian hampir seluruh siswa mengalami kesulitan belajar dengan tingkat kesulitan yang tinggi, faktor yang paling dominan menyebabkan siswa mengalami kesulitan belajar berasal dari faktor diri sendiri yaitu sebesar $70.9 \%$, kemudian disusul oleh faktor lingkungan sekolah sebanyak $68.9 \%$. Sedangkan faktor lingkungan keluarga merupakan faktor yang paling rendah yang mempengaruhi kesulitan belajar siswa yaitu sebesar 50.1\%. Faktor dari diri sendiri yang mempengaruhi kesulitan belajar siwa adalah sebagai berikut; 1). Kesiapan Belajar, hal yang dapat penulis lihat pada saat pelaksanaan PPL dan penelitian adalah kurangnya kesiapan siswa untuk mengikuti pelajaran, hal ini ditandai dengan banyak diantara siswa yang tidak memiliki buku pelajaran IPA dan sering lupa membawa peralatan belajar, sehingga pada saat proses pembelajaran berusaha meminjam kepada teman-teman atau bahkan sampai tidak menegerjakan tugas hanya karena kendala tersebut. Sesuai dengan Husdarta, dkk (2013) bahwa siswa akan mendapatkan hasil belajar yang maksimal tergantung pada kesiapan siswa mengikuti pelajaran.

Kesiapan belajar merupakan kondisi yang harus dapat perhatian pertama sebelum kegiatan belajar. Tanpa adanya kesiapan belajar siswa untuk belajar mustahil terjadi proses belajar; 2. Minat, hampir seluruh siswa tidak menyukai pelajaran IPA dengan alasan bahwa pelajaran IPA tersebut tidak menyenangkan. Banyaknya penggunaan bahasa ilmiah merupakan salah satu hal yang membuat siswa menjadi tidak bermint untuk mengikuti pelajaran; dan 3). Motivasi, siswa kelas VII kurang memiliki motivasi hal ini dapat dlihat dari tidak antusiasnya untuk mengikuti pelajaran. Banyak siswa yang masih dengan santainya duduk di kantin sekolah meskipun bel masuk telah berbunyi. Menurut Husdarta (2013) motivasi yang berasal dari dalam diri siswa itu sendiri merupakan hal yang sangat penting. Sebagai pelajar, ia harus mampu membangkitkan motivasi dengan menetapkan sendiri tujuan yang ingin dicapai dan mengelola sendiri upaya untuk mencapainya. 


\section{KESIMPULAN}

Berdasarkan hasil penelitian, dapat disimpulkan bahwa sebanyak $1.6 \%$ siswa mengalami kesulitan belajar kategori sangat tinggi, $71.1 \%$ mengalami kesulitan belajar kategoi tinggi, dan 27. $3 \%$ sisanya mengalami kesulitan belajar kategori sedang. Faktor yang mempengaruhi kesulitan belajar yang dialami siswa dapat dilihat berdasarkan hasil angket faktor kesulitan belajar, bahwa siswa mengalami kesulitan belajar yang bersumber dari faktor internal, yaitu diri sendiri sebesar $70.9 \%$, dan dari faktor eksternal yaitu dari faktor lingkungan keluarga sebesar $50.1 \%$ dan dari lingkungan sekolah sebesar $68.9 \%$. Karena itu faktor kesulitan belajar mempunyai kontribusi terhadap hasil belajar, ternyata menunjukkan hubungan signifikan antara kedua variabel tersebut sehingga kesimpulannya adalah bahwa faktor kesulitan belajar mempunyai kontribusi terhadap hasil belajar.

\section{REFERENSI}

Abin S.M., 2002. Diagnostik Kesulitan Belajar. Jurnal Pendidikan. https://ebekunt.wordpress.com

Muahaemin, A.D.,2006. Upaya Meningkatkan Pemahaman Konsep Biologi Pada Siswa Kelas 2 Semester Ganjil SMP Al- Kautsar TP. 2004/2005Melalui Pendekatan Peta Konsep.Jurnal Pendidikan dan Pembelajaran Vol 4, no.1. Edisi Maret.

Agustin M., 2011. Permasalahan Belajar Dan Inovasi Pembelajaran. Bandung: Refika Aditama.

Arikunto S., 2012. Dasar-dasar Evaluasi Pendidikan Edisi 2. Jakarta: Bumi Aksara.

Faturrahman, dkk., 2012. Pengantar Pendidikan. Jakarta: Prestasi Pustakarya.

Hamalik O., 2013. ProsesBelajar Mengajar. Bumi Aksara, Jakarta.

Husdarta, S., 2013. Belajar Dan Pembelajaran. Alfabeta, Bandung.

Mukhadis I. D., 2003. Tahapan Proses Penelitian Deskriptif. Jurnal Pendidikan.

Purwanto N., 2013. Evaluasi Hasil Belajar. Alfabeta, Bandung. 2013. Psikologi Pendidikan. Remaja Rosdakarya, Bandung.

Sapuroh S. 2010. “Analisis Kesulitan Belajar Siswa Dalam Memahami Konsep Biologi Pada Konsep Monera" (Skripsi_tidak publikasi). Fakultas Ilmu Tarbiyah Dan Keguruan. UIN Syarif Hidayatullah. Jakarta.

Sugiyono. 2011. Metode Peneltian Kuatitatif Kualitatif Dan R\&D. Alfabeta, Bandung. 